\title{
A Mathematical Study of Break-Even Analysis Based on Dairy Farms in Bangladesh
}

\author{
Jinnat Ara ${ }^{1}$, Mir Md. Moheuddin ${ }^{2,}$, Saddam Hossain ${ }^{3}$, Muhammad Abdus Sattar Titu ${ }^{4}$ \\ ${ }^{1}$ Department of Applied Mathematics, Noakhali Science and Technology University (NSTU), Noakhali, Bangladesh \\ ${ }^{2}$ Department of CSE (Mathematics), Atish Dipankar University of Science and Technology (ADUST), Dhaka, Bangladesh \\ ${ }^{3}$ Department of Basic Science (Mathematics), World University of Bangladesh (WUB), Dhaka, Bangladesh \\ ${ }^{4}$ Department of Mathematics (General Science), Mymensingh Engineering College (MEC), Mymensingh, Bangladesh
}

Email address:

jinnataraprema51@gmail.com (J. Ara), mirmdmoheuddinkhan@gmail.com (M. Md. Moheuddin), s.hossain656@gmail.com (S. Hossain), titumec@gmail.com (Md. A. S. Titu)

${ }^{*}$ Corresponding author

\section{To cite this article:}

Jinnat Ara, Mir Md. Moheuddin, Saddam Hossain, Muhammad Abdus Sattar Titu. A Mathematical Study of Break-Even Analysis Based on Dairy Farms in Bangladesh. International Journal of Economic Behavior and Organization. Vol. 8, No. 2, 2020, pp. $38-43$.

doi: $10.11648 /$ j.ijebo.20200802.13

Received: May 22, 2020; Accepted: June 11, 2020; Published: June 23, 2020

\begin{abstract}
Break-even analysis is the analysis of the level of sales at which a company would make zero profit and it assists management in determining the number of products to be produced to attain desired profits, the number of products to be produced at a minimum threshold level, gaining desired profits under different cost and volume relationship. This technique has been applied to focus on how selling prices, the volume of sales, total costs such as variable cost and fixed costs as well as the mix of product sold affects profit. This research study aimed to determine the profitability position of several dairy farms in Bangladesh based on their cost-volume of the production. The study is conducted on two dairy farms named as Subarna AgroBased Initiative and Nusrat Agro \& Dairy Farm in Noakhali district. To obtain the objectives, ten years of financial data are taken from the period of 2009-10 to 2018-19 in the form of primary data. Utilizing these data profit volume ratio (P/V ratio), break-even point (BEP) and margin of safety are calculated for ten years. From the analysis, a P/V ratio from 2009-10 to 201819 is gradually raised and also break-even point demonstrates an optimal level considering the level of sales volume in ten years. Besides, the margin of safety helps us to know the risk level of a business. As-a-results, this article will lead to making how much cost to be spent to produce the required number of volumes of products to achieve the desired profit goal.
\end{abstract}

Keywords: Break-Even Analysis, Profit Volume Ratio, Break-Even Point, Margin of Safety

\section{Introduction}

Break-even analysis is an analytical process related to the study of cost-volume-profit relationships and evaluating the point of sales volume where total revenue is equal to total costs, which is called a break-even point (BEP). It is a financial tool that can be applied by managers to determine the impact of costs and revenue on profitability. At the break-even point, we know that total sales revenue that is equal to total business costs $[$ i.e. $\mathrm{TR}=\mathrm{TC}$ ], where $\mathrm{TR}=$ Selling Price $[\mathrm{SP}] \times$ Quantity Sold and TC $=$ Fixed Costs $[\mathrm{FC}]+$ Variable Costs [VC]. In Bangladesh, more than half of the people are based on agricultural and livestock farming. Dairying is one of the major components of animal agriculture and part of a mixed farming system in Bangladesh. The average milk production in Bangladesh is less due to the low productivity of dairy animals, and lack of proper care as well as management. A break-even analysis informs a business owner how much they need to sell out monthly, quarterly, or annually for the sake of covering their business costs. Nowadays, Break-even analysis plays an inevitable role which enables us to take a proper decision making, planning as well as controlling the business farms. It gives a clear concept of dairy farms mathematically and is interpreted through a graph easily.

In Review of Literature, we have seen that several authors in business and marketing literature discuss the uses of break-even analysis and all of them utilize the unstable 
perfectly competitive firm's break-even analysis formula and/or diagram and apply them to all situations-including imperfectly competitive firms. Moreover, Chandra et al. were done the study of break-even point analysis to estimate the minimum quantity milk to be produced to cover the total cost on all categories (members and nonmembers) of households of milch animals (Cow and Buffalo). And they also have found out the total cost of milk production per liter for member and nonmember categories [1]. M. Sultana et al. showed the sustainable conditions of cooperative in the dairy sector of Bangladesh. In their paper, they also analyzed the conditions of dairy farmers in Bangladesh who are members and not members of the agriculture cooperative with a case study [2]. I. Akin et al. evaluated the economic efficiency of DD treatment on milk yield in lame cows suffering from DD. A total of 33 Holstein dairy cows with DD were included in their study [3]. In addition, C. A. Durham et al. utilized an economic model to evaluate the net present value (NPV), internal rate of return, and payback period for artisan cheese production at different annual production volumes [4]. Muhammad Abdus Sattar Titu et al. studied on both the primary and secondary data and information. The main research issues covered in their study were: adoption of online banking facilities in Bangladesh, identifying major components of online banking and their application, knowing the main online banking services offered by the selected banks, assessing customer satisfaction on online banking service and identifying the major problems of online banking service in selected banks [5]. Dr. R. Kavitha had taken Salem Steel Authority of India Limited, Tamilnadu which was one among the steel industries in India to measure the profitability position through BEP analysis [6]. Besides, various discussion of break-even analysis and financial management is described in the books of R. Michael et al., Sheeba Kapil, O. R Krishnaswami, Dr. S. N. Maheshwari et al. [7-10].

What's more, R. S. Abdullahi described cost volume profit analysis as an estimate of how changes in costs (Both variable and Fixed) sales volume and price affect the company's profit [11]. M. B. Ndaliman et al. suggested a thorough application of breakeven analysis to improve profit levels of small manufacturing firms [12]. Dr. Nabil Alnasser et al. analyzed to figure out the effect of using breakeven point in planning, controlling, and in the decision-making process, in the Jordanian industrial companies [13]. Also, Ferdous Alam conducted to measure the technical (TE), allocative (AE), and cost efficiency (CE) of pangas fish - producing farmers of Bangladesh [14]. Abdul et al. presented the Relationship between cost management and profitability: A study of selected manufacturing firms [15]. Ali Uyar represented the Cost and Management Accounting Practices: A Survey of Manufacturing Companies [16]. Further, A. W. Patrick demonstrates Some Observations on the Break-Even Chart [17]. IlhanDalci et. Al showed about Activity-Based CostVolume-Profit Analysis: Another Approach to Break-Even Analysis [18]. M. A. S. khan presented for the Performance of Different Genetic Group of Cows Bangladesh Condition [19].
S. A. M. Haque discussed Bangladesh: Social gains from dairy development [20]. U. K. Datta introduced a new pricing approach under a cost-based pricing approach and break-even analysis by redefining the fixed costs [21].

In this paper, our analysis is mainly focused on two dairy farms in the Noakhali district named Subarna Agro-Based Initiative and Nusrat Agro \& Dairy Farm. This study is prepared to find out the farm's profitability based on their Cost-Volume of the manufacture using break-even analysis. To fulfill the objectives, the profit volume ratio has been analyzed, and also the effect of break-even point has been identified for both farms.

The whole paper is organized as follows: in section 2, we introduce an overview of materials and methods. In Section 3 , we analyze the results and discussion of our works. Section 4 highlights a discussion of findings. Finally, section 5 includes a conclusion of our paper.

\subsection{Statement of the Problem}

The economy of Bangladesh is the first and foremost on agriculture and livestock which is an essential component of the rural economy and livelihood of the subsistence farmers. Dairy farming is a part and parcel of the integrated farming system in Bangladesh. There are many commercial dairy firms in Bangladesh. The study is undertaken to examine the profitability position of several dairy farms in Bangladesh. For these two dairy farms are chosen. Subarna Agro-Based Initiative and Nusrat Agro \& Dairy Farm are the most prevalent dairy farms in the Noakhali district. The major problems of large scale industries to sustain Cost-Volume level and to determine their profit level from their operations.

\subsection{Study Area and Cattle Population}

The cattle and dairy improvement farms, Subarna AgroBased Initiative (SABI) and Nusrat Agro \& Dairy Farm (NADF), are the non-government dairy farms located in Noakhali Sadar Upazilla under Noakhali district. There were 63 cattle populations in SABI and 45 cattle populations in NADF from 2018 to 2019.

\subsection{Objectives of the Study}

The main objectives of our paper are given below:

To analyze the profit volume ratio for computing profitability of sales.

To identify the break-even point which helps to determine the minimum output that must be exceeded to make a profit.

To compute the margin of safety ratio for minimizing the risk of business losses.

\section{Materials and Methods}

For this research ten years of financial data are taken from the period of 2009-10 to 2018-19 in the form of primary data. The data are collected from records books of respective farms and uncertainty was met discussing with owners, managers and employs. In this study, Subarna Agro-Based 
Initiative and Nusrat Agro \& Dairy Farm have taken to analyze the cost volume, profitability position at different levels. To compensate for the goal, the study needs

To analyze the profit volume ratio ( $\mathrm{P} / \mathrm{V}$ ratio).

To identify the break-even point (BEP).

To calculate the margin of safety ratio (MOS).

\subsection{Profit Volume Ratio (P/V ratio)}

The $\mathrm{P} / \mathrm{V}$ ratio, which establishes the relationship between contribution and sales, is of vital importance for studying the profitability of operations of a business. It reveals the effect on profit of changes in the volume. Higher the $\mathrm{P} / \mathrm{V}$ ratio, more will be the profit and lower the $\mathrm{P} / \mathrm{V}$ ratio, lesser will be the profit. Thus, every management aims at increasing the $\mathrm{P} / \mathrm{V}$ ratio. The $\mathrm{P} / \mathrm{V}$ ratio is also called the 'contribution ratio' or 'marginal ratio' and can be expressed as under:

$$
\mathrm{P} / \mathrm{V} \text { Ratio }=\frac{\text { Contribution }}{\text { Sales }}
$$

Since Contribution $=$ Sales - Variable Cost $=$ Fixed Cost + Profit

$\mathrm{P} / \mathrm{V}$ ratio can also be expressed as:

$$
\begin{gathered}
\mathrm{P} / \mathrm{V} \text { Ratio }=\frac{\text { Sales-Variable Cost }}{\text { Sales }} \text { i.e. } \frac{\mathrm{S}-\mathrm{V}}{\mathrm{S}} \\
\text { Or, P/V Ratio }=\frac{\text { Fixed Cost }+ \text { Profit }}{\text { Sales }} \text { i.e. } \frac{\mathrm{F}+\mathrm{P}}{\mathrm{S}}
\end{gathered}
$$

Or, $\mathrm{P} / \mathrm{V}$ Ratio $=$ Change in Profit or Contribution/Change in Sales

This ratio can also be shown in the form of percentage by multiplying by 100 .

\subsection{Break-Even Point (BEP) Analysis}

Break-even point (BEP) indicates the level of operations that produce neither profit nor loss.

By determining this point, the firm can assess precisely how it is away from the point. If the firm operates at a level above the BEP, it indicates that the firm is making a profit. Thus, cost revenue relationship at the BEP can be expressed as:

Total fixed costs + Total variable costs $=$ Total sales revenue

Fixed costs: Fixed costs are those costs which do not change with variation in the level of production activity. These costs are unavoidable expenses. They vary only with time. In a dairy farm, the fixed costs are salary/honor, the return of investment, rent, depreciation value etc.

Variable costs: Variable costs include expenses which fluctuate in correspondence with variation in the level of output and sales. In a dairy farm, the variable costs are feed, medicine, electricity \& water pump, all services, equipment etc.

To calculate the break-even point, first, we need to calculate the contribution margin. The contribution margin is a company's sales less its variable expenses. Then, divide the company's fixed costs by the contribution margin.

$$
\mathrm{BEP}=\frac{\text { Total Fixed Cost }}{\text { Sales }- \text { Variable Cost }} \times \text { Sales }
$$

If the firm is to avoid losses it must make a break-even volume of sales which produces a margin of income above variable costs that equals the number of fixed costs incurred during the period. Higher the volume of sales concerning the break-even level larger would be the volume of profit of the enterprise.

\subsection{The Margin of Safety (MOS)}

With the help of break-even point margin of safety of the firm can be found out. The margin of safety is the difference between the total sales and the sales at the break-even point. The size of the margin of safety (expressed in monetary terms or as a percentage to total sales) is indicative of the strength of a business enterprise.

The margin of safety can be calculated in the following manner:

The margin of safety $=$ Actual sales - Sales at the breakeven point

The margin of safety can be expressed as a percentage of sales.

$$
\text { The margin of safety ratio }=\frac{\text { Actual sales }-\mathrm{BE} \text { sales }}{\text { Actual sales }} \times 100
$$

A firm to be strong enough must have a high margin of safety so that even if there is a fall in sales, it can make a profit. This analysis helps the firms to focus more on profitable products and services as compared to other ones.

\section{Results and Discussion}

\subsection{Break-Even Analysis of Subarna Agro-Based Initiative (SABI)}

Ratio analysis, break-even point analysis, and margin of Safety tools are used to know the profitable position and risk position of the dairy farm.

\subsubsection{P/V Ratio Analysis of SABI}

The $\mathrm{P} / \mathrm{V}$ ratio is the measurement of the rate of change of profit due to change in volume of sales. It is one of the important ratios for computing profitability as it indicates contribution earned with respect to sales. Contribution means the difference between the sales price and variable cost. The table below shows the $\mathrm{P} / \mathrm{V}$ ratio of Subarna Agro-Based Initiative of ten years separately.

Table 1. The profit volume ratio of SABI (In Tk.).

\begin{tabular}{llll}
\hline Years & Contribution & Sales & P/V Ratio \\
\hline $2009-10$ & 3291000 & 5362600 & 0.614 \\
$2010-11$ & 3789100 & 6059500 & 0.625 \\
$2011-12$ & 3971800 & 6651800 & 0.597 \\
$2012-13$ & 3670200 & 6366200 & 0.577 \\
$2013-14$ & 3913300 & 6472900 & 0.605 \\
$2014-15$ & 4772700 & 7756000 & 0.615 \\
$2015-16$ & 5504400 & 8069400 & 0.682 \\
$2016-17$ & 4974200 & 7822700 & 0.636 \\
$2017-18$ & 5299400 & 8544700 & 0.620 \\
$2018-19$ & 4795900 & 7959500 & 0.603 \\
\hline
\end{tabular}


The profit volume ratio table shows the relationship between contribution and sales. In the case of Subarna AgroBased Initiative, the $\mathrm{P} / \mathrm{V}$ ratio shows a decreasing propensity 2009-10, 2011-12 \& 2016-17. When the $\mathrm{P} / \mathrm{V}$ ratio is high it indicates the high-profit margin. A low $\mathrm{P} / \mathrm{V}$ ratio indicates a low-profit margin. In the cases of low margin, the farm has to either increase the selling price to improve the $\mathrm{P} / \mathrm{V}$ ratio or increase the sales turnover to earn satisfactory profit in the business. The situation of high $\mathrm{P} / \mathrm{V}$ ratio is called a profitable situation. In the year $2015-16$, the $\mathrm{P} / \mathrm{V}$ ratio occupies the highest position i.e., 0.682 and lowest position in the year 2012-13 i.e., 0.577 .

\subsubsection{Break-Even Point Analysis of SABI}

The break-even point (BEP) or break-even level represents the sales amount - in either unit (quantity) or revenue (sales) terms - that is required to cover total costs, consisting of both fixed and variable costs to the farm. Total profit at the breakeven point is zero. It is only possible for a firm to pass the break-even point if the sales are higher than the variable costs per unit. This means that the selling price of the good must be higher than what the company paid for the good or its components for them to cover the initial price they paid (variable and fixed costs). Once they surpass the break-even price, the company can start making a profit. The table below shows the break-even point of the Subarna Agro-Based Initiative of ten years separately.

Table 2. Break-even point of SABI (In Tk.).

\begin{tabular}{lllll}
\hline Years & Fixed Cost & $\begin{array}{l}\text { Variable } \\
\text { Cost }\end{array}$ & Sales & $\begin{array}{l}\text { Break-Even } \\
\text { Point }\end{array}$ \\
\hline $2009-10$ & 2545200 & 2071600 & 5362600 & 4147338.05 \\
$2010-11$ & 2633800 & 2270400 & 6059500 & 4211953.00 \\
$2011-12$ & 2718400 & 2680000 & 6651800 & 4552659.53 \\
$2012-13$ & 3048900 & 2696000 & 6366200 & 5288514.84 \\
$2013-14$ & 3067000 & 2559600 & 6472900 & 5073054.53 \\
$2014-15$ & 3743000 & 2983300 & 7756000 & 6082659.29 \\
$2015-16$ & 4084600 & 2565000 & 8069400 & 5987986.20 \\
$2016-17$ & 3833900 & 2848500 & 7822700 & 6029401.62 \\
$2017-18$ & 4157800 & 3245300 & 8544700 & 6703995.48 \\
$2018-19$ & 3876000 & 3163600 & 7959500 & 6432790.93 \\
\hline
\end{tabular}

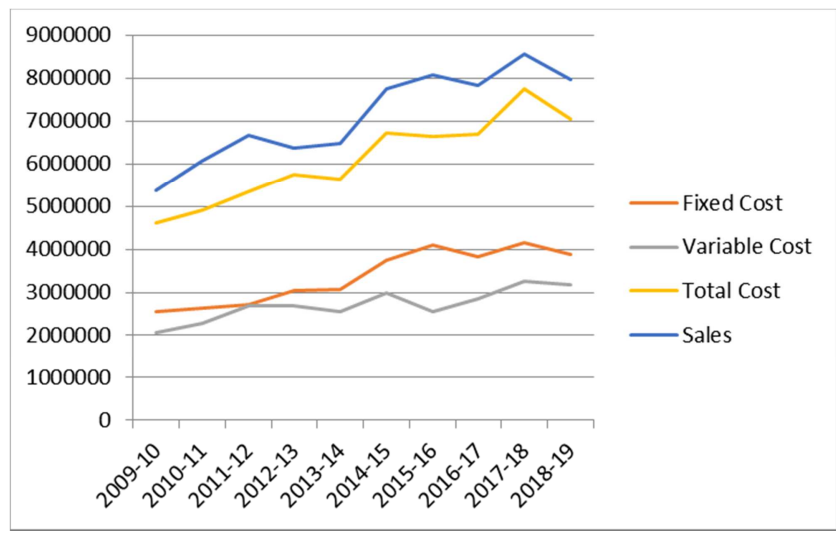

Figure 1. Break-even chart of SABI.

The table shows that BEP analysis in the year 2009-10 to 2018-19 is favourable levels. Higher the BEP indicates in the year 2017-18 i.e., 6703995.48. From 2009-10 to 2018-19, every year total costs are changed based on the level of sales. Therefore, it is terminated that the farm earns sufficient profit depending upon their cost and volume of sales. Furthermore, figure 1 gives a clear depiction about the cost and volume of sales from 2009-10 to 2018-19.

\subsubsection{The Margin of Safety of SABI}

The difference between actual sales and sales at the break-even point represents the margin of safety. Since break-even analysis assumes that production will correspond to sales, the margin of safety may also be considered to be excess production over break-even production. This excess may be expressed in absolute terms as well as in terms of percentage of sales. The table below shows the margin of safety of the Subarna Agro-Based Initiative for ten years separately.

Table 3. The Margin of safety of SABI (In Tk.).

\begin{tabular}{lllll}
\hline Years & $\begin{array}{l}\text { Actual } \\
\text { sales }\end{array}$ & $\begin{array}{l}\text { Break-Even } \\
\text { sales }\end{array}$ & $\begin{array}{l}\text { Margin of } \\
\text { safety }\end{array}$ & $\begin{array}{l}\text { Margin of } \\
\text { safety ratio }\end{array}$ \\
\hline $2009-10$ & 5362600 & 4147338.05 & 1215261.95 & 22.66 \\
$2010-11$ & 6059500 & 4211952.10 & 1847547.00 & 30.49 \\
$2011-12$ & 6651800 & 4552659.53 & 2099140.47 & 31.56 \\
$2012-13$ & 6366200 & 5288514.84 & 1077685.16 & 16.93 \\
$2013-14$ & 6472900 & 5073054.53 & 1399845.47 & 21.63 \\
$2014-15$ & 7756000 & 6082659.29 & 1673340.71 & 21.57 \\
$2015-16$ & 8069400 & 5987986.20 & 2081413.80 & 25.79 \\
$2016-17$ & 7822700 & 6029401.62 & 1793298.38 & 22.92 \\
$2017-18$ & 8544700 & 6703995.48 & 1840704.52 & 21.54 \\
$2018-19$ & 7959500 & 6432790.93 & 1526709.07 & 19.18 \\
\hline
\end{tabular}

The margin of safety tells us the number of sales that can be dropped before losses begin to be incurred. With a high margin of safety, business has a low risk of not breaking even and with a low margin of safety, business has a high risk of not breaking even. The table indicates the margin of the safety level of Subarna Agro-Based Initiative in the year 2011-12 occupies the climax stage of $31.56 \%$ and very low ratio shows in the year 2012-13 i.e., $16.93 \%$. Hence, the higher the margin of safety has a more profitable position of the concern. The farm should concentrate on sales volume to reduce the loss/risk.

\subsection{Break-Even Analysis of Nusrat Agro \& Dairy Farm (NADF)}

Ratio analysis, break-even point analysis, and margin of Safety tools are used to know the profitable position and risk position of the dairy farm.

\subsubsection{P/V Ratio Analysis of NADF}

The $\mathrm{P} / \mathrm{V}$ ratio is the measurement of the rate of change of profit due to change in volume of sales. It is one of the important ratios for computing profitability as it indicates contribution earned with respect to sales. Contribution means the difference between the sales price and variable cost. The table below shows the $\mathrm{P} / \mathrm{V}$ ratio of Nusrat Agro \& Dairy Farm of ten years separately. 
Table 4. The profit volume ratio of NADF (In Tk.).

\begin{tabular}{llll}
\hline Years & Contribution & Sales & P/V Ratio \\
\hline $2009-10$ & 2251900 & 3942500 & 0.571 \\
$2010-11$ & 2383500 & 3888000 & 0.613 \\
$2011-12$ & 2408050 & 4697050 & 0.513 \\
$2012-13$ & 2474000 & 4448900 & 0.556 \\
$2013-14$ & 2915500 & 4969500 & 0.587 \\
$2014-15$ & 3266700 & 5063200 & 0.645 \\
$2015-16$ & 3317000 & 4875000 & 0.680 \\
$2016-17$ & 3991400 & 5354400 & 0.745 \\
$2017-18$ & 3762000 & 5173000 & 0.727 \\
$2018-19$ & 3468700 & 4965000 & 0.698 \\
\hline
\end{tabular}

The profit volume ratio table shows the relationship between contribution and sales. In the case of Nusrat Agro \& Dairy Farm, the $\mathrm{P} / \mathrm{V}$ ratio shows a decreasing propensity 2009-10, 2011-12 \& 2017-18. When the $\mathrm{P} / \mathrm{V}$ ratio is high it indicates the high-profit margin. A low $\mathrm{P} / \mathrm{V}$ ratio indicates a low-profit margin. In the cases of low margin, the farm has to either increase the selling price to improve the $\mathrm{P} / \mathrm{V}$ ratio or increase the sales turnover to earn satisfactory profit in the business. The situation of high $\mathrm{P} / \mathrm{V}$ ratio is called a profitable situation. In the year 2016-17, the $\mathrm{P} / \mathrm{V}$ ratio occupies the highest position i.e., 0.745 and lowest position in the year 2011-12 i.e., 0.513.

\subsubsection{Break-Even Point Analysis of NADF}

The break-even point (BEP) or break-even level represents the sales amount - in either unit (quantity) or revenue (sales) terms - that is required to cover total costs, consisting of both fixed and variable costs to the farm. Total profit at the breakeven point is zero. It is only possible for a firm to pass the break-even point if the sales are higher than the variable costs per unit. This means that the selling price of the good must be higher than what the company paid for the good or its components for them to cover the initial price they paid (variable and fixed costs). Once they surpass the break-even price, the company can start making a profit. The table below shows the break-even point of Nusrat Agro \& Dairy Farm for ten years separately.

Table 5. Break-even point of NADF (In Tk.).

\begin{tabular}{lllll}
\hline Years & Fixed Cost & $\begin{array}{l}\text { Variable } \\
\text { Cost }\end{array}$ & Sales & $\begin{array}{l}\text { Break-Even } \\
\text { Point }\end{array}$ \\
\hline $2009-10$ & 1865000 & 1690600 & 3942500 & 3265137.22 \\
$2010-11$ & 1648500 & 1504500 & 3888000 & 2689057.26 \\
$2011-12$ & 1957800 & 2289000 & 4697050 & 3818809.61 \\
$2012-13$ & 1739600 & 1974900 & 4448900 & 3128256.44 \\
$2013-14$ & 2386500 & 2054000 & 4969500 & 4067814.01 \\
$2014-15$ & 2453000 & 1796500 & 5063200 & 3802011.08 \\
$2015-16$ & 2492000 & 1558000 & 4875000 & 3662496.23 \\
$2016-17$ & 2764500 & 1363000 & 5354400 & 3708533.05 \\
$2017-18$ & 2593000 & 1411000 & 5173000 & 3565547.32 \\
$2018-19$ & 2334600 & 1496300 & 4965000 & 3341681.03 \\
\hline
\end{tabular}

The table shows that BEP analysis in the year 2009-10 to 2018-19 is favourable levels. Higher the BEP indicates in the year 2013-14 i.e., 4067814.01. From 2009-10 to 2018-19, every year total costs change based on the level of sales. Therefore, it is terminated that the farm earns sufficient profit depending upon their cost and volume of sales. Furthermore, figure 2 gives a clear depiction about the cost and volume of sales from 2009-10 to 2018-19.

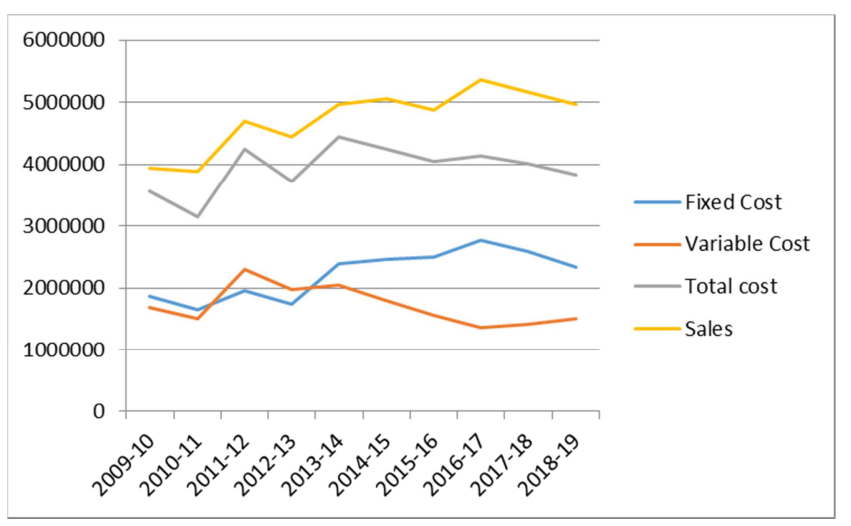

Figure 2. Break-even chart of $N A D F$

\subsubsection{The Margin of Safety of $\mathrm{NADF}$}

The difference between actual sales and sales at the breakeven point represents the margin of safety. Since break-even analysis assumes that production will correspond to sales, the margin of safety may also be considered to be excess production over break-even production. This excess may be expressed in absolute terms as well as in terms of percentage of sales. The table below shows the margin of safety of Nusrat Agro \& Dairy Farm for ten years separately.

Table 6. The margin of the safety of NADF (In Tk.).

\begin{tabular}{lllll}
\hline Years & $\begin{array}{l}\text { Actual } \\
\text { Sales }\end{array}$ & $\begin{array}{l}\text { Break-Even } \\
\text { Sales }\end{array}$ & $\begin{array}{l}\text { Margin of } \\
\text { Safety }\end{array}$ & $\begin{array}{l}\text { Margin of } \\
\text { Safety Ratio }\end{array}$ \\
\hline $2009-10$ & 3942500 & 3265137.22 & 677362.78 & 17.18 \\
$2010-11$ & 3888000 & 2689057.26 & 1198942.74 & 30.84 \\
$2011-12$ & 4697050 & 3818809.61 & 878240.39 & 18.70 \\
$2012-13$ & 4448900 & 3128256.44 & 1320643.56 & 29.68 \\
$2013-14$ & 4969500 & 4067814.01 & 901685.99 & 18.14 \\
$2014-15$ & 5063200 & 3802011.08 & 1261188.92 & 24.91 \\
$2015-16$ & 4875000 & 3662496.23 & 1212503.77 & 24.87 \\
$2016-17$ & 5354400 & 3708533.05 & 1645866.95 & 30.74 \\
$2017-18$ & 5173000 & 3565547.32 & 1607452.68 & 31.07 \\
$2018-19$ & 4965000 & 3341681.03 & 1623318.97 & 32.70 \\
\hline
\end{tabular}

The margin of safety tells us the number of sales that can be dropped before losses begin to be incurred. With a high margin of safety, businesses have a low risk of not breaking even and with a low margin of safety, businesses have a high risk of not breaking even. The table indicates the margin of the safety level of Nusrat Agro \& Dairy Farm in the year 2018-19 occupies the climax stage of $32.70 \%$ and very low ratio shows in the year 2009-10 i.e., $17.18 \%$. Hence, the higher the margin of safety has a more profitable position of the concern. The farm should concentrate on sales volume to reduce the loss/risk.

\section{Discussion of Findings}

From the above analyses, it is clear that if:

There is an increase in selling price per unit. It will increase the $\mathrm{P} / \mathrm{V}$ ratio, reduce the break-even point and increase the margin of safety. If there is a reduction in price 
per unit, it will decrease the $\mathrm{P} / \mathrm{V}$ ratio, increase the breakeven point and shorten the margin of safety.

There is an increase in variable cost per unit, it will decrease the $\mathrm{P} / \mathrm{V}$ ratio, increase the breakeven point and shorten the margin of safety.

There is an increase in total fixed costs, there will be no effect on $\mathrm{P} / \mathrm{V}$ ratio, increase the break-even point and shorten the margin of safety.

There is an increase in no. of units sold, it will have no effect on $\mathrm{P} / \mathrm{V}$ ratio and break-even point but will increase the margin of safety.

\section{Conclusion}

Based on the results, the study concludes management may utilize break-even analysis for calculating the profit yield by a given amount of selling goods. The management may set the necessary sales level with a view to earning the desired profit using the break-even analysis. After analyzing the several data which are related to Subarna Agro-Based Initiative and Nusrat Agro \& Dairy Farm, it is found that every year total costs are charged based on the volume of sales. Besides, it is suggested that the farms earn adequate profit depending upon their cost and volume of sales. In our article, both the farms of each year must have a higher or lower break-even point. Each farm develops a break-even point calculation, as this will enable them to see the number of units they need to sell to cover their variable costs. However, this study also represents that the margin of safety is a vital role for any business due to it says to management how much reduction in revenue will result in a break-even. A higher margin of safety decreases the risk of business losses.

\section{References}

[1] Chandra, Ashish, et al. "Cost of Milk Production and Break Even Analysis of Member and Non Member of Dairy Cooperative Society for Milch Animals (Cow \& Buffalo) in District Etawah of UP." Cost of Milk Production and Break Even Analysis of Member and Non Member of Dairy Cooperative Society for Milch Animals (Cow \& Buffalo) in District Etawah of UP (June 18, 2014) (2014).

[2] Sultana, M., Ahmed, J. U., \& Shiratake, Y. (2020). Sustainable conditions of agriculture cooperative with a case study of dairy cooperative of Sirajgonj District in Bangladesh. Journal of Co-operative Organization and Management, 8 (1), 100105.

[3] Akin, I., \& Akin, T. (2018). Economic impact of digital dermatitis treatment on a dairy farm: an application of the break-even analysis. Ciência Rural, 48 (8).

[4] Durham, C. A., Bouma, A., \& Meunier-Goddik, L. (2015). A decision-making tool to determine economic feasibility and break-even prices for artisan cheese operations. Journal of dairy science, 98 (12), 8319-8332.

[5] Titu M. A. S. et al. Online Banking System-Its Application in Some Selected Private Commercial Banks in Bangladesh, IOSR Journal of Business and Management (IOSR-JBM) eISSN: 2278-487X, p-ISSN: 2319-7668. Volume 9, Issue 4
(Mar. - Apr. 2013), PP 37-44, www.iosrjournals.org.

[6] Kavitha R. Dr., Cost Volume Profitability Analysis - An Empirical Study With Reference To Salem Steel Authority of India Limited (SAIL), Tamilnadu, International Journal of Business and Management Invention (IJBMI) ISSN (Online): $2319-8028$, ISSN (Print): $2319-801 X$.

[7] Michael R., Kinney, Cecily A. Raiborn, Cost Accounting Foundations and Evolutions New Delhi (Cengage Learning Publications, 2009).

[8] Sheeba Kapil, Financial Management (Pearson Publications, New Delhi, 2011).

[9] Krishnaswami O. R and Ranganathan M., Methodology of Research in Social Sciences (Himalaya Publishing House, Mumbai, 2016).

[10] Maheshwari S. N. Dr., Sharad, K. Maheshwari, Financial and Management Accounting (New Delhi: Sultan Chand \& Sons, 2010).

[11] Abdullahi, R. S. (2015). Mastering Cost and Management Accounting. (3rd ed) Kano: Sharif Mahir Investment Ltd.

[12] Ndaliman, M. B., \&. Bala, K. C. (2007). Practical Limitations of Breakeven theory.

[13] Nabil Alnasser Dr., Osama Samih Shaban Dr., Ziad Al Zubi Dr., The Effect if Using Break-Even-Point in Planning, Controlling, and Decision Making in the Industrial Jordanian Companies, Internatinal Journal of Academic Research in Business and Sicial Sciences, May 2014, Vol. 4, No. 5 ISSN: 2222-6990.

[14] Alam, Ferdous. "Measuring technical, allocative and cost efficiency of pangas (Pangasius hypophthalmus: Sauvage 1878) fish farmers of Bangladesh." Aquaculture Research 42, no. 10 (2011): 1487-1500.

[15] Abdul et. al (2015), "Relationship between cost management and profitability: A study of selected manufacturing firms", International Journal of Management Sciences and Humanities, Volume-3, Issue-2, ISSN: 2360-9214.

[16] Ali Uyar (2010), "Cost and Management Accounting Practices: A Survey of Manufacturing Companies", Eurasian Journal of Business and Economics, Volume- 3. Issue- (6). pp 113-125.

[17] Patrick, A. W. "Some Observations on the Break-Even Chart." Accounting Review (1958): 573-580.

[18] IlhanDalci et. al (2005), "Activity-Based Cost-Volume-Profit Analysis: Another Approach to Break-Even Analysis". C. U. Sosyal Bilimler Enstitusu Dergisi, Volume 14, Issue 2, pp 227244.

[19] Khan, M. A. S., Siddiki, M. S. R. and Uddin, M. E (2010). Performance of Different Genetic Group of Cows Bangladesh Condition. Bang. J. Anim. Sci., 22 (1): 26-43.

[20] Haque, S. A. M., 2009. Bangladesh: Social gains from dairy development. In: Animal Production and Health Commission for Asia and the Pacific and Food and Agriculture Organization (APHCA-FAO) publication on smallholder dairy development: Lessons learned in Asia, RAP publication 2009/2.

[21] Datta, U. K. (2017). COST-BASED PRICING APPROACH AFTER BREAK-EVEN IN MARKETING FOR SMALL \& MEDIUM ENTERPRISES (SMEs). Management, 31 (2). 